\title{
Processos de iniciação à vida cristã e resiliência: um estudo teológico-pastoral sobre a catequese com adultos na Paróquia Nossa Senhora dos Navegantes (Diadema/SP)
}

Orientador: Abimar Oliveira de Moraes

Doutorando: Eduardo Antonio Calandro

Área de Concentração: Teologia Sistemático-Pastoral

Linha de Pesquisa: Fé e Cultura

Projeto de Pesquisa: Questões atuais de Pastoral Profética

A presente pesquisa é um diálogo entre a Teologia Pastoral e a Psicologia Positiva, temas que se correlacionam e, ao mesmo tempo, nos desafiam dado que nos propomos a fazer uma reflexão interdisciplinar. É uma urgência na Igreja o processo de iniciação à vida cristã que conduza a pessoa ao encontro pessoal e comunitário a Jesus Cristo, isso só é possível por intermédio de uma consistente experiência de fé vivenciada a partir de um itinerário catequético que orienta todo o agir do iniciante, potencializando, assim, a resiliência frente às adversidades do cotidiano. Pretendemos refletir, a partir de um estudo de campo, sobre os aspectos teológicos-pastorais da catequese com adultos e analisar a importância de todo o seu itinerário como promotora de resiliência. $O$ processo da iniciação à vida cristã não se esgota na preparação aos sacramentos, mas é caminho para o seguimento e adesão a Jesus Cristo, deve ser feito e refeito, tanto quando for necessário, com a meta de inserir a pessoa na comunidade cristã. Neste estudo, a resiliência é entendida como capacidade para superar situações adversas e a experiência de fé vivenciada em todo o itinerário é considerada uma alavanca, algo a mais que uma pessoa possui para ser resiliente. É uma pesquisa qualitativa, de caráter exploratório, com orientação analítico-hermenêutica, mediante a técnica do grupo focal com questões 
abertas. Os sujeitos são os adultos que participam da catequese na paróquia Nossa Senhora dos Navegantes, em Diadema. O estudo teológico-pastoral dos dados coletados seguiu a técnica de análise de Bardin. Seguindo os relatos dos participantes, todo o processo da iniciação à vida cristã é o caminho ordinário, coerente e consistente para ajudar uma pessoa a iniciar e aprofundar a experiência de fé que lhe dá a capacidade para desenvolver-se bem, para continuar projetando-se apesar dos acontecimentos desestabilizadores e das condições de vida difíceis. $\mathrm{O}$ itinerário catequético que conduz o adulto ao seguimento de Jesus Cristo e o insere na comunidade cristã é capaz também de ajudá-lo a superar, aprender ou mesmo ser transformado com a adversidade que é inevitável à vida.

Palavras-chave: Iniciação à vida cristã. Catequese com adultos. Psicologia positiva. 